\title{
PROFIL PENYAKIT MALARIA PADA PENDERITA RAWAT INAP DI RUMAH SAKIT UMUM DAERAH KOTA BITUNG
}

\author{
Diana S. Purwanto ${ }^{1}$ \\ Ronald I. Ottay ${ }^{2}$ \\ ${ }^{1}$ Bagian Biokimia Fakultas Kedokteran Universitas Sam Ratulangi Manado \\ ${ }^{2}$ Bagian Ilmu Kedokteran Pencegahan Fakultas Kedokteran \\ Universitas Sam Ratulangi Manado \\ Email: shintapurwanto@yahoo.co.id
}

\begin{abstract}
To date, malaria is still a public health problem in Indonesia, because some areas are still endemic. Malaria in North Sulawesi is included in the top ten diseases prevalent in the health centers and hospitals. Some type $\mathrm{C}$ hospitals, including the district hospitals and some private hospitals, play an important role in treating patients with malaria and its complications. Data of malaria patients in hospitals were only obtained from several hospitals in Manado and Minahasa. The purpose of this research is to get the profile of malarial patients hospitalized in the general hospital of Bitung regency during the period of January 2008 until December 2009. The research method used was a retrospective survey of records from malarial patients' medical records at the general hospital of Bitung regency. The collected data were then processed, arranged in a frequency distribution tables, and discussed according to: age, sex, occupation, residence, clinical symptoms, laboratory examination, complications, treatment, and diagnosis. This study described that the accuracy and precision of handling malarial patients in this hospital was still low, as seen in the type of treatment, which showed that the use of antimalarial drugs were only about $6-37 \%$ correctly given, and about $1-10 \%$ showing incorrect use. Moreover, from the clinical diagnosis of malaria, there were only 60 cases $(36 \%)$ with positive plasmodium and the most frequent entry diagnosis was febrile observation.
\end{abstract}

Keywords: malaria, plasmodium, a retrospective survey

\begin{abstract}
Abstrak: Di Indonesia sampai saat ini penyakit malaria masih merupakan masalah kesehatan masyarakat karena beberapa daerah masih merupakan daerah endemis. Di Sulawesi Utara penyakit malaria termasuk dalam urutan atas dari sepuluh penyakit menonjol di puskesmas dan rumah sakit. Beberapa rumah sakit tipe $\mathrm{C}$ yaitu rumah sakit kabupaten/kota dan beberapa rumah sakit swasta sangat berperan dalam mengobati penderita malaria dan komplikasinya. Data-data mengenai penderita malaria di rumah sakit, hanya didapatkan dari beberapa rumah sakit saja khususnya yang berada di Manado dan Minahasa. Tujuan dari penelitian ini untuk mendapatkan gambaran penyakit malaria pada penderita rawat inap di Rumah Sakit Umum Daerah Bitung periode Januari 2008 sampai dengan Desember 2009. Metode penelitian yang digunakan yaitu survei retrospektif terhadap catatan rekam medik penderita malaria di Rumah Sakit Umum Daerah Bitung. Data yang didapat kemudian diolah, disusun dalam bentuk tabel distribusi frekuensi, dan dibahas menurut: usia, jenis kelamin, pekerjaan, tempat tinggal, gejala klinis, pemeriksaan laboratorium, komplikasi, pengobatan dan diagnosis masuk. Hasil penelitian ini menunjukkan kecepatan dan ketepatan penanganan di rumah sakit tersebut masih kurang dilihat dari jenis pengobatan, dimana ditemukan penggunaan obat antimalaria hanya sekitar 6-37 \% yang diberikan secara benar dan ada sekitar 1-10 \% yang penggunaannya masih salah. Juga diagnosis malaria secara klinis hanya dijumpai pada 60 kasus $(36 \%)$ plasmodium positif dan diagnosis masuk terbanyak adalah observasi febris.
\end{abstract}

Kata kunci: malaria, plasmodium, survei retrospektif 
Malaria merupakan penyakit infeksi yang disebabkan oleh plasmodium, dan mempunyai gambaran karakteristik: demam periodik, anemia dan hepatosplenomegali. ${ }^{1,2}$ Penyakit ini cenderung untuk bermanifestasi dari keadaan akut ke menahun. Selama stadium akut terdapat masa demam yang intermiten. Selama stadium menahun berikutnya, terdapat masa laten yang diselingi oleh relaps beberapa kali. ${ }^{1,2}$

Berat ringannya manifestasi malaria tergantung jenis plasmodium yang menyebabkan infeksi. Dikenal empat jenis plasmodium yaitu $P$. vivax yang merupakan infeksi paling sering dan menyebabkan malaria tertiana/vivaks; $P$. falciparum yang memberikan banyak komplikasi dan mempunyai perlangsungan yang cukup ganas, mudah resisten terhadap pengobatan dan menyebabkan malaria tropika/ falciparum; P. malariae yang sering menimbulkan sindroma nefrotik dan menyebabkan malaria quartana/malariae; dan $P$. ovale yang dijumpai pada daerah Afrika dan Pasifik Barat, memberikan infeksi yang paling ringan dan sering sembuh spontan tanpa pengobatan, dan menyebabkan malaria ovale. ${ }^{3}$

Gejala subjektif penderita malaria pada waktu masuk rumah sakit di Rumah Sakit Umum Pusat Manado (sekarang Rumah Sakit Prof. dr. R.D. Kandou) dan Rumah Sakit Bethesda Tomohon umumnya simtomatik berupa demam 92-96\%, sakit kepala 79-94\%, menggigil 64-82\%, mual $74-76 \%$, pusing $75-82 \%$, nyeri epigastrium $31-52 \%$ dan muntah $31-37 \%$. Gejala objektif yang ditemui pada kasus malaria di Rumah Sakit Bethesda Tomohon pada tahun 1993 antara lain splenomegali 40,7\%, hepatomegali $43 \%$, pucat $6,6 \%$ dan ikterik $3,0 \%{ }^{4}$

Malaria masih merupakan masalah kesehatan di banyak negara di seluruh dunia. Tiga ratus juta penduduk diserang setiap tahunnya, dan 2-4 juta meninggal dunia. ${ }^{1}$ Di Indonesia sampai saat ini penyakit malaria masih merupakan masalah kesehatan masyarakat, karena beberapa daerah masih merupakan daerah endemis.
Walaupun telah dilakukan program pelaksanaan dan pemberantasan penyakit malaria sejak tahun 1959, namun hingga saat ini angka kesakitan dan kematian masih cukup tinggi. Oleh karena itu Departemen Kesehatan memberikan prioritas tinggi untuk penyakit malaria. ${ }^{5}$

Di Sulawesi Utara penyakit malaria termasuk dalam urutan atas dari sepuluh penyakit menonjol di puskesmas dan rumah sakit. Sekitar 9\% dari kasus rawat inap di rumah sakit ialah infeksi malaria. ${ }^{6}$ Setiap tahun terdapat 30-40 kasus malaria berat dan 400 malaria ringan, dengan jumlah kematian setiap tahun 6-7 orang. Untuk kota Manado sendiri, angka kematian dari penderita malaria berat adalah $15,7 \%$, dengan komplikasi terbanyak yaitu ikterus dan gagal ginjal akut. ${ }^{7}$

Di kota Bitung, penyakit ini menempati urutan ketiga dari sepuluh penyakit menonjol, dengan jumlah kasus di tahun 2008 sebesar 3516 kasus, dan di tahun 2009 sejumlah 2606 kasus. Data yang ditemukan di Rumah Sakit Umum Daerah Bitung memperlihatkan penyakit malaria berada pada urutan ketiga dari 10 penyakit menonjol.

Mengenai penanggulangan malaria, perlu ditekankan pentingnya penegakkan diagnosis dini dari kasus-kasus malaria, di samping pemberian pengobatan yang sempurna dan membuat rujukan yang tepat. Untuk menegakkan diagnosis dini malaria dibutuhkan pengetahuan mengenai gejalagejala klinik malaria pada umumnya, dan yang lebih penting lagi ialah pengetahuan tentang malaria berat atau malaria yang berkomplikasi.

Beberapa rumah sakit tipe $\mathrm{C}$ yaitu rumah sakit kabupaten/kota dan beberapa rumah sakit swasta sangat berperan dalam mengobati penderita malaria dan komplikasinya. Hanya saja kecepatan dan ketepatan penanganan di rumah sakit kabupaten/kota tersebut masih tergantung akan fasilitas dan sumber daya manusia. Data-data mengenai penderita malaria di rumah sakit, hanya didapatkan dari beberapa rumah sakit saja khususnya yang berada di Manado dan Minahasa. ${ }^{8}$ Penelitian ini bertujuan un- 
tuk mendapatkan gambaran penyakit tersebut pada penderita rawat inap di Rumah Sakit Umum Daerah Kota Bitung periode Januari 2008 sampai dengan Desember 2009.

\section{TINJAUAN PUSTAKA}

Masa inkubasi malaria bervariasi pada masing-masing plamodium, paling pendek pada $P$. falciparum dan paling panjang pada $P$. malariae. Masa inkubasi ini tergantung pula pada intensitas infeksi, pengobatan yang pernah didapat sebelumnya dan tingkat imunitas penderita. Keluhan prodromal dapat terjadi sebelum terjadinya demam berupa: kelesuan, malaise, sakit kepala, sakit belakang, nyeri pada tulang/otot, anoreksia, perut berasa tidak enak, diare ringan dan kadang-kadang merasa dingin di punggung. 3,4

Gejala klasik yaitu terjadinya "trias malaria" (malaria paroxysm) secara berurutan: periode dingin, periode panas dan periode berkeringat. Trias malaria secara keseluruhan dapat berlangsung 6-10 jam, dan lebih sering terjadi pada infeksi $P$. vivax. Pada $P$. falciparum menggigil dapat berlangsung berat atau tidak ada. Periode tidak panas berlangsung 12 jam pada $P$. falciparum, 36 jam pada P.vivax dan ovale, dan 60 jam pada P.malariae. Keadaan anemia dan pembesaran limpa sering dijumpai pada penderita malaria. Limpa merupakan organ penting dalam pertahanan tubuh terhadap infeksi malaria. Limpa akan teraba tiga hari dari serangan infeksi akut, kemudian menjadi bengkak, nyeri dan hiperemis. Dijumpainya riwayat demam dengan anemia dan splenomegali merupakan petunjuk untuk diagnosis infeksi malaria khususnya di daerah endemik. ${ }^{3,4}$

Untuk pemeriksaan laboratorium, berbagai cara dapat dilakukan yaitu dari pemeriksaan konvensional dengan microskop cahaya untuk mengevaluasi sediaan darah yang diwarnai dengan Giemsa (pemeriksaan gold standard) sampai pada berbagai pemeriksaan yang lebih modern dengan menggunakan mikroskop fluoresensi, flow cytometry, automated blood cell analyser, pemeriksaan serologi, berbagai metode molekular maupun dengan laser desorption mass spectrometry. ${ }^{9,10}$

Diagnosis didasarkan pada gejala serta tanda klinis seperti disebutkan di atas, ditambah hasil pemeriksaan preparat malaria dengan ditemukannya parasit plasmodium dalam darah penderita sebagai diagnosis definitif. Diagnosis juga sering memerlukan anamnesis yang tepat dari penderita mengenai: asal penderita, apakah dari daerah endemik malaria; riwayat bepergian ke daerah malaria; atau riwayat pengobatan kuratif maupun preventif. ${ }^{11}$

Obat antimalaria yang ideal adalah obat yang efektif terhadap semua jenis dan stadia parasit, menyembuhkan infeksi akut maupun laten, cara pemakaian mudah, harga terjangkau oleh seluruh lapisan masyarakat, mudah diperoleh, efek samping ringan, dan toksisitas rendah. ${ }^{12}$ Tujuan pengobatan ialah penyembuhan klinis dan parasitologik, serta memutuskan rantai penularan. $^{13}$

Kegagalan dalam melakukan pengobatan terhadap malaria ringan dapat menyebabkan terjadinya malaria berat atau meluasnya malaria karena transmisi infeksi; hal ini dapat menyebabkan infeksi berulang atau gejala berulang (re-infeksi atau rekrudesensi), bahkan timbulnya resistensi. WHO telah merekomendasikan pengobatan malaria secara global dengan penggunaan regimen obat ACT (Artemisin Combination Therapy). Oleh karena itu, komisi ahli malaria dari Depkes RI sejak tahun 2004 telah menyetujui pengunaan obat ACT sebagai obat lini pertama di seluruh Indonesia. ${ }^{13}$

\section{METODE PENELITIAN}

Desain penelitian ini bersifat deskriptif dengan metode survei retrospektif. Penelitian dilaksanakan di Rumah Sakit Umum Daerah Bitung. Sampel penelitian ini yaitu semua penderita malaria yang pernah dirawat inap di Rumah Sakit Umum Daerah Bitung dari 1 Januari 2008 sampai dengan 31 Desember 2009 yang sesuai dengan kriteria inklusi. Yang termasuk 
kriteria inklusi yaitu: penderita yang didiagnosis malaria, diobati malaria secara pengobatan terapeutik, sembuh atau meninggal karena malaria, sedangkan kriteria eksklusi yaitu: penderita malaria yang disertai penyakit lain. Variabel dari penelitian ialah usia, jenis kelamin, pekerjaan, tempat tinggal, gejala klinis, pemeriksaan laboratorium, komplikasi, pengobatan dan diagnosis masuk rumah sakit.

\section{HASIL PENELITIAN}

Berdasarkan hasil penelitian di Rumah Sakit Umum Daerah Bitung, ditemukan bahwa penderita rawat inap pada periode Januari 2008 sampai Desember 2009 mencakup 175 kasus. Dari distribusi jenis kelamin terlihat bahwa kasus malaria lebih banyak ditemukan pada laki-laki (89 kasus, $50,9 \%$ ) daripada perempuan (86 kasus, $49,1 \%$ ), dengan perbandingan $1,03: 1$. Hal ini hampir sama dengan yang dilaporkan Datau et al $(1975,1980)$ dan Pangalila (1984, 1987), dengan perbandingan 1,3-2,2 : 1). ${ }^{14}$ Hal ini berhubungan dengan faktor perilaku yang diduga sangat berperan. Pada hakekatnya laki-laki lebih banyak terlibat dalam mobilisasi penduduk, sebagai contoh: dalam hal pekerjaan, banyak laki-laki yang bekerja sebagai pekerja musiman (di daerah endemik), atau menjadi penjaga ladang pada malam hari. Selain itu, banyak laki-laki yang memiliki kegemaran memancing ikan di kolam atau sungai pada malam hari. Perilaku seperti ini mempermudah kontak manusia dengan vektor sehingga dapat diprediksikan penderita malaria laki-laki lebih banyak daripada perempuan. ${ }^{15,16}$

Kelompok usia yang paling banyak menderita malaria pada penelitian ini ialah kelompok umur 31-40 tahun (43 kasus, $24,6 \%$ ). Kelompok usia yang paling sedikit menderita malaria ialah kelompok umur 0-10 tahun (1 kasus, 0,6\%). Hasil ini sesuai dengan penelitian Soemyarso (1986), dimana kelompok usia 31-40 tahun merupakan kelompok usia produktif sehingga diduga banyak melakukan aktivitas di luar rumah, yang mempermudah kontak dengan vektor pembawa parasit malaria. Usia 0-10 tahun, terutama $\leq 1$ tahun masih mendapatkan perhatian penuh dari orang tua, sehingga lebih terhindar dari gigitan nyamuk. ${ }^{17}$ Selain itu, di daerah endemi, bayi berusia 3-6 bulan yang lahir dari ibu yang imun, mempunyai imunitas yang diturunkan, sehingga meskipun terdapat hiperparasitemia dan ada kalanya demam, mereka jarang mengalami malaria berat. ${ }^{18}$

Berdasarkan jenis pekerjaan, ibu rumah tangga merupakan kelompok terbanyak dari yang bekerja, yaitu 42 kasus (24 $\%)$. Walaupun dengan jenis pekerjaan ini tidak banyak melakukan aktivitas di luar rumah, namun diduga lingkungan tempat tinggal penderita dan sekitarnya merupakan daerah endemis malaria atau banyak mengandung vektor pembawa parasit malaria. Meskipun demikian, dari hasil ini terlihat bahwa malaria menyerang semua lapisan ekonomi masyarakat (kelompok perempuan), tanpa perbedaan dalam jenis pekerjaan.

Berdasarkan distribusi tempat tinggal, diperoleh bahwa sebagian besar penderita malaria bertempat tinggal di Kecamatan Matuari (52 kasus, 29,6 \%). Hal ini mungkin disebabkan karena Rumah Sakit Umum Daerah Bitung terletak di Kecamatan Matuari sehingga penderita yang datang berobat sebagian besar berdomisili di kecamatan tersebut.

Keluhan waktu masuk rumah sakit semuanya menderita demam (175 kasus, 100 $\%)$. Hal ini tidak jauh berbeda dengan yang dilaporkan Gautama (95 \%) dan Soemyarso $(100 \%) .{ }^{16}$ Terdapat juga keluhan lain yang menonjol yaitu menggigil (77 kasus, $44 \%$ ), badan lemah (65 kasus, 37,1\%) dan sakit kepala (51 kasus, 29,1\%). Dengan adanya demam, menggigil, badan lemah dan sakit kepala pada penderita, mungkin menjadi dasar untuk didiagnosis sebagai penyakit malaria secara klinis. Keluhan lain, seperti muntah (36 kasus, 20,6 \%), mual (32 kasus, $18,3 \%$ ), nyeri ulu hati (32 kasus, 18,3\%) dan nafsu makan menurun (35 kasus, $20 \%$ ) lebih merupakan manifestasi dari penyakit saluran cerna (gastritis, tukak lambung dan 
sebagainya). Penelitian di Thailand mengemukakan bahwa pada pemeriksaan endoskopik penderita malaria dijumpai gambaran gastritis; pada keadaan tersebut, pengobatan dengan antasida dapat mengganggu absorbsi obat anti malaria yang digunakan. ${ }^{4}$

Berdasarkan pemeriksaan fisik ditemukan penderita dengan splenomegali (48 kasus, 27,4 \%), hepatomegali (27 kasus, 15,4 $\%)$ dan ikterus (6 kasus, 3,4\%). Hasil ini berbeda dengan yang ditemukan oleh Hardiono dan Subandijo, yaitu hepatomegali (72 \%) lebih banyak daripada splenomegali $(58 \%)$ dan ikterus $(6 \%) .{ }^{19}$ Juga berbeda dari penelitian prospektif Datau et al yang mendapatkan hepatomegali 65,7 \% dan splenomegali $37 \%{ }^{20}$ Perbedaan ini tergantung pada beberapa hal, antara lain ketrampilan dan ketelitian pemeriksa.

Dalam kurun waktu dua tahun didapatkan 167 kasus $(84,6 \%)$ malaria positif dengan perincian 146 kasus $(83,4 \%)$ malaria falsiparum dan 21 kasus (12\%) malaria vivaks; selain itu juga ditemukan plasmodium negatif pada 8 kasus $(4,6 \%)$. Hasil yang negatif ini mungkin disebabkan karena parasitemia yang rendah sehingga tidak terdeteksi, namun bisa juga karena kurangnya ketelitian petugas laboratorium pada waktu pemeriksaan darah.

Berdasarkan hasil pemeriksaan hemoglobin, ternyata lebih dari $50 \%$, baik pada laki laki maupun perempuan, mempunyai kadar hemoglobin masih normal, dan hanya 2 kasus $(2,3 \%)$ pada laki-laki dan 1 kasus $(1,2 \%)$ pada perempuan dengan anemia berat. Hal ini mungkin disebabkan karena yang lebih banyak datang berobat yaitu penderita dengan infeksi malaria akut, namun demikian tidak terdapat hubungan bermakna antara anemia dan parasitemia. Anemia sendiri tidak bisa digunakan sebagai prediktor yang baik untuk malaria. $^{21}$

Jenis pengobatan yang terbanyak diberikan ialah klorokuin secara tunggal (38 kasus, 21,7 \%). Hal ini sesuai dengan pernyataan bahwa di Indonesia, klorokuin masih merupakan first line drug untuk pengobatan malaria. Ini disebabkan klorokuin dinilai sangat efektif, juga mudah didapat dengan harga relatif terjangkau. Selain klorokuin, juga terdapat pemberian kombinasi dua, tiga bahkan empat obat anti malaria. Penulis tidak mendapati alasan pemberian kombinasi obat tersebut pada catatan rekam medik penderita; mungkin kombinasi tersebut diberikan karena tidak terdapat perbaikan atau respon klinis terhadap satu macam obat, atau untuk mencegah terjadinya malaria berat. Dewasa ini WHO merekomendasikan pemberian obat antimalaria kombinasi untuk mengatasi kegagalan terapi terhadap $P$. falciparum dengan monoterapi. Obat antimalaria kombinasi adalah penggunaan dua atau lebih obat antimalaria yang bersifat skizontosida darah dengan mekanisme kerja yang berbeda dan target biokimia yang berbeda terhadap parasit. Tujuan penggunaan obat antimalaria kombinasi ialah untuk meningkatkan efektivitas terapi dan mencegah atau memperlambat timbulnya resistensi terhadap obat tunggal. $^{22}$

Berdasarkan ketepatan penggunaan obat antimalaria (klorokuin, artesunat, kina, Suldox dan primakuin) baik regimen maupun dosis, ternyata hanya sekitar 74,695,6\% kasus yang diberikan secara benar, sedangkan pada 4,4-25,4 \% penggunaannya masih salah. Pengobatan malaria yang salah baik dalam regimen maupun dosisnya mengakibatkan kadar obat dalam darah suboptimal, sehingga menyebabkan kegagalan dalam terapi dan mempermudah terjadinya resistensi. ${ }^{12}$

Pada pengamatan diagnosis masuk penderita yaitu 167 kasus $(95,4 \%)$ dengan malaria positif dan 8 kasus $(4,6 \%)$ malaria negatif, ternyata paling banyak didiagnosis saat masuk sebagai observasi febris (4-29,9 $\%$ ), sedangkan klinis malaria hanya sebanyak 16-19 \%. Hal ini menunjukkan bahwa ketajaman diagnosis yang masih kurang dan pengetahuan tentang gejala klinis malaria hanya sekitar 16-19 \%. Juga ditemukan sindroma dispepsia dan gastritis, masing-masing sebanyak 7,2\%. Pada daerah endemis, parasitemia sering ditemukan 
pada orang dewasa tanpa gejala malaria. Hal ini mengakibatkan pasien menjadi asimtomatik, sehingga yang menonjol ialah gejala lainnya seperti keluhan saluran cerna berupa mual-muntah, sakit perut dan kadang-kadang diare. ${ }^{23}$

\section{SIMPULAN}

Hasil penelitian ini menunjukkan bahwa kecepatan dan ketepatan penanganan di Rumah Sakit Umum Daerah Kota Bitung periode Januari 2008 sampai dengan Desember 2009 masih kurang dilihat dari jenis pengobatan malaria yang diberikan, baik mengenai regimen pengobatan maupun dosis. Diagnosis malaria secara klinis masih kurang, dan diagnosis masuk terbanyak ialah observasi febris.

\section{SARAN}

Penting dilakukan suatu penelitian lanjut untuk mencari tahu faktor-faktor yang menyebabkan transmisi malaria lebih banyak di daerah Matuari daripada daerah Bitung lainnya. Dalam hal ini perlu dilakukan pelatihan lanjutan terhadap petugas laboratorium untuk meningkatkan ketepatan dalam mendeteksi parasit secara laboratorik. Juga perlu pelatihan terhadap para dokter agar dapat mendiagnosis malaria klinis secara lebih baik dan sosialisasi kembali tentang penggunaan dosis dan regimen pengobatan malaria yang benar.

\section{DAFTAR PUSTAKA}

1. Pribadi W, Sungkar S. Malaria. Jakarta: Balai Penerbit FKUI, 1994.

2. Rampengan TH, Laurentz IR. Penyakit Infeksi Tropik pada Anak. Jakarta: EGC, 1993.

3. Harijanto PN. Gejala klinis malaria ringan. Dalam: Harijanto PN, Nugroho A, Gunawan CA, editor. Malaria dari Molekul ke Klinis (Edisi ke-2). Jakarta: EGC, 2008; p.85-102.

4. Harijanto PN. Gejala klinik malaria. Dalam: Harijanto PN, editor. Malaria Epidemiologi, Patogenesis, Manifestasi Klinis, \& Penanganan (Edisi ke-1).
Jakarta: EGC, 2000; p.151-65.

5. Simanjuntak CH, Arbani PR. Status malaria di Indonesia. CDK. 1999;55:311.

6. Suparman E. Malaria pada kehamilan. CDK. 2005;146:19.

7. Nugroho A, Harijanto PN. Profile of severe malaria at Manado general hospital, Indonesia. International Journal of Infectious Diseases. 2008;12(1):315-5.

8. Gunawan CA, Harijanto PN, Sutjipto. Malaria di Sulawesi Utara. Dalam: Harijanto PN, editor. Malaria Epidemiologi, Patogenesis, Manifestasi Klinis, \& Penanganan (Edisi ke-1). Jakarta: EGC, 2000; p.27-37.

9. Alisah S, Abidin N, Susanto L. Diagnosis malaria dengan metode lama dan baru. MKI. 1997;47(2):75-8.

10. Sutanto I. Diagnosis mikroskopik dan serologik malaria. Dalam: Harijanto PN, Nugroho A, Gunawan CA, editor. Malaria dari Molekul ke Klinis (edisi ke-2). Jakarta: EGC, 2008; p.103-17.

11. Purwaningsih $\mathbf{S}$. Diagnosis malaria. Dalam: Harijanto PN, editor. Malaria Epidemiologi, Patogenesis, Manifestasi Klinis, \& Penanganan (Edisi ke-1). Jakarta: EGC, 2000; p.185-93.

12. Tjitra E. Obat antimalaria. Dalam: Harijanto PN, editor. Malaria Epidemiologi, Patogenesis, Manifestasi Klinis, \& Penanganan (Edisi ke-1). Jakarta: EGC, 2000; p.195-223.

13. Harijanto PN. Pengobatan malaria tanpa komplikasi. Dalam: Harijanto PN, Nugroho A, Gunawan CA, editor. Malaria dari Molekul ke Klinis (edisi ke-2). Jakarta: EGC, 2008; p.145-55.

14. Datau AE, Waworuntu M. Prevalensi malaria dan faktor-faktor yang mempengaruhi di tiga desa di Kotamadya Manado. Manado: FK Unsrat, 1991; p.1-3.

15. Tandayu SA. Masalah data malaria di Sulawesi Utara. Dalam: Tambayong EH, editor. Penanganan Malaria Secara Terpadu. Manado: FK Unsrat, 1993; p.155-63.

16. Waleleng BJ, Harijanto PN, Datau AE. Pola klinik, Komplikasi dan Mortalitas Malaria Serebral di RSUP Gunung Wenang Manado. Manado: FK Unsrat, 1992; p.1-7.

17. Soemyarso N. Insiden malaria pada anak 
yang dirawat di Rumah Sakit Umum Daerah Tingkat I Propinsi Bengkulu tahun 1986. MKI. 1988;38(9):424-6.

18. Langi J, Harijanto PN, Richie TL. Patogenesa malaria berat. Dalam: Harijanto PN, editor. Malaria Epidemiologi, Patogenesis, Manifestasi Klinis, \& Penanganan (Edisi ke-1). Jakarta: EGC, 2000; p.119-27.

19. Hardiono, Subandijo A. Malaria di Rumah Sakit Umum R.A. Kartini, Jepara. Medika. 1988;14(6):522-7.

20. Datau AE. Diagnosis klinik malaria. Dalam: Tambayong EH, editor. Penanganan Malaria Secara Terpadu. Manado: FK Unsrat, 1993; p.55-63.
21. Syafrudin D, Asih PB, Wahid I, Dewi RM, Tuti S, Laowo I, et al. Malaria prevalence in Nias District, North Sumatra Province, Indonesia. Malaria Journal. 2007;6(116):1-8.

22. Gunawan CA. Obat antimalaria. Dalam: Harijanto PN, Nugroho A, Gunawan CA, editor. Malaria dari Molekul ke Klinis (Edisi ke-2). Jakarta: EGC, 2008; p.118-44.

23. Hermawan F, Harijanto PN. Kegagalan dalam diagnosis malaria di RSU Bethesda GMIM Tomohon Sulawesi Utara. Surabaya: Kopapdi XI, 2000; p.18. 